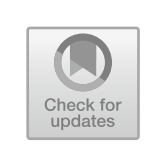

\title{
The Plymouth Company and Massachusetts Bay Company (1622-1639): Establishing Theocratic Corporate Governance
}

Two years after the massacre of 1622, James I revoked the VC's charter and Virginia was placed under direct Crown rule. The demise of the VC served as an example to future companies of the perils of establishing an ineffective form of religious governance. As John Winthrop wrote in 1629, 'those plantations, which have been formerly made, succeeded ill', as they had made 'great and fundamental errors' and consequently did 'not establish the right form of government'. ${ }^{1}$ For those who became leaders in the $\mathrm{MBC}$, the $\mathrm{VC}$ provided a potent memory of the dangers of establishing the wrong form of religious governance overseas. Seen as 'unfit instruments' their failure to regulate the social, commercial and, importantly, religious behaviour of English and indigenous people in America was at the forefront of the minds of many of those who would be involved in the MBC. ${ }^{2}$ Virginia and the experiences of the VC cemented the place of religious governance as a mechanism of behavioural regulation in companies. However, other than providing the foundations for religious governance, the $\mathrm{VC}$ did not define the model or character of religious governance that companies such as the $\mathrm{MBC}$ and EIC chose to establish and adapt.

1 'General Observation for the Plantation of New England' (1629) in Winthrop Papers, 5 vols. (Boston, MA Historical Society, 1929-1947), II: pp. 117, 114.

2 Ibid, p. 114; Kupperman, Jamestown, pp. 326-327. 
Established five years after the dissolution of the VC, the MBC took its charter and government to New England, and unlike its southern predecessor established a form of government almost entirely autonomous from England. Uniformly made up of Nonconformist communities who had either fled from or were currently being subjected to the growing calls for uniformity in the established Church, the company developed a form of religious governance that mirrored their beliefs. ${ }^{3}$ Through their corporate charter, the MBC's members obtained the structural framework to legitimise and establish a form of theocratic governance that policed the religious behaviour of its personnel, securing the godly society that they had been unable to attain in England.

The company's first governor in New England described the MBC's mission to be a 'city upon a hill' wherein the eyes of the world would watch them establish their godly government. ${ }^{4}$ As the MBC settled itself in New England, the purpose of its religious governance, unlike the VC, was to establish a form of godly theocratic governance, based on the Congregationalist principles of its members. Their theocratic model of governance was an example of the 'purity they [the English] could achieve in America' and would be an example not only to Native American communities in New England, but also to those they had left behind in England, of godly governance. ${ }^{5}$ Furthermore, although the company and its members physically separated themselves from England geographically, their association with Congregationalism provided it with a support network within Nonconformist communities in England. Unlike the VC and its sermons, the presence of a financially and vocally supportive religious community in England obviated the need to cultivate support for their model of religious governance; rather, it already existed. This chapter examines the formation of theocratic governance in the MBC, assessing how the corporate charter both provided and legitimised its

${ }^{3}$ Francis Rose-Troup, The Massachusetts Bay Company and its Predecessors (New York, NY: Grafton Press, 1930); Alexander Young, ed., Chronicles of the First Planters of the Colony of Massachusetts Bay, -1636 (Boston, MA: Charles C. Little and James Brown, 1846); Thomas Hutchinson, ed., The History of Massachusetts: From the Settlement Thereof in 1628 Until the Year 1750, 2 vols. (Salem, 1795); N. B. Shurtleff, ed., Records of the Governor and Company of the Massachusetts Bay New England, 5 vols. (Boston, MA: W. White, 1853-1854).

${ }^{4}$ John Winthrop, A Model of Christian Charity (1630), in Collections of the Massachusetts Historical Society (Boston, 1833), VII, $3^{\text {rd }}$ series: p. 47 (hereafter MHSC).

5 Moore, Pilgrims, pp. 45-50. 
authority. Moreover, it traces how both these governmental elements of the company worked in conjunction to regulate the behaviour of the colony's English population.

Focusing on the Atlantic world in the years following the demise of the VC, this chapter investigates England's New England companies and their members' development of models of religious governance based on their theological beliefs. Recent work has laid the foundations to gain a 'reliable handle on the explanations that actors gave for their behaviour'; however, this chapter develops our understanding of the corporate framework and model of religious governance that regulated those actors' behaviour. ${ }^{6}$ The focus of this investigation is the corporate foundations and the charters of the PC and the MBC and how they provided the structural base for a community to develop a model of governance around the companies' theocratic Congregationalist principles. In establishing this structural base, those in the government that was settled in Massachusetts were perceived by many in England to have 'turned their backs on the Church of England', establishing a uniquely 'New English' form of religious governance. ${ }^{7}$ Furthermore, this chapter highlights the impact England's denominational variation had on the character of religious governance abroad, in comparison with the EIC. It does so by investigating the development of corporate government in New England through the formation of the theocratic model of governance that marked the transition between 'godly ecclesiastical republicanism' and 'godly civic republicanism' in the seventeenth century. ${ }^{8}$ The chapter studies the manner in which corporations offered the opportunity for religious communities to congregate or covenant together to secure their authority and regulate behaviour through uniformity.

Once established in the New England wilderness 3,300 miles from authorities in England, the membership of the MBC was quick to get to work establishing their model of theocratic governance. Incited by growing religious and political intolerance in England, those who ventured to Massachusetts formally established a society based on Presbyterian and Congregational republicanism that had developed in England

\footnotetext{
${ }^{6}$ Winship, Godly Republicanism, p. 11.

7 Moore, Pilgrims, p. 7.

${ }^{8}$ Winship, Godly Republicanism, p. 10.
} 
since the late sixteenth century. ${ }^{9}$ In her work on migration to and from Massachusetts, Susan Hardman Moore has highlighted how North East America became a centre for such heterogeneity, dispute and experimentation, as Nonconformist groups of various theological backgrounds fled from England and were able 'to co-exist in the Bay Colony'. ${ }^{10}$ Despite some exceptions, the vast majority of those who migrated to Massachusetts from 1630 onwards did so in order to escape the 'reach of Archbishop William Laud long arm' in order to establish a godly polity that would be governed by broadly agreed upon Nonconformist, Congregational principles. ${ }^{11}$

In addition, despite the MBC government's open policing of trade, the focus has often been on its religious settlement, so that historians have often dismissed the MBC's 'corporate' credentials in favour of defining it as a colonial enterprise. ${ }^{12}$ The MBC corporate charter not only provided its leadership with a mechanism of English governance but also a legal constitutional connection, beyond the migrants' English birth, to the government within Old England. ${ }^{13}$ Similar to the 'financial ties and legal obligations' which connected families in New and Old England, the charter was a constitutional and legal apparatus of English governance

${ }^{9}$ Winship, Godly Republicanism; Winship, 'Godly Republicanism', pp. 427-462; Maloy, Colonial American Origins; Robert F. Scholz, 'Clerical Consociation in Massachusetts Bay: Reassessing the New England Way and Its Origins', William and Mary Quarterly, Vol. 29, No. 3 (1972); Stephen Foster, The Long Argument: English Puritanism and the Shaping of New England Culture, 1500-1700 (Chapel Hill, NC: University North Carolina Press, 1991); J. T. Peacey, 'Seasonable Treatises: A Godly Project of the 1630s', English Historical Review, Vol. 113, No. 452 (1998), pp. 667-679.

${ }^{10}$ Moore, Pilgrims, pp. 6-7.

11 Peter J. Thuesen, Predestination: The American Career of a Contentious Doctrine (Oxford: Oxford University Press, 2009), p. 47.

12 John Fredrick Martin, Profits in the Wilderness: Entrepreneurship and the Founding of New England Towns in the Seventeenth Century (Chapel Hill, NC: University of North Carolina Press, 2014); Bernard Bailyn, The New England Merchants in the Seventeenth Century (Cambridge, MA: Harvard University Press, 1955); Ruth A. McIntyre, Debts Hopeful and Desperate: Financing the Plymouth Colony (Plymouth, MA: Plimoth Plantation, 1963).

13 David Grayson Allen, In English Ways: The Movement of Societies and Transferal of English Local Law and Customs to Massachusetts in the Seventeenth Century (Chapel Hill, NC: University of North Carolina Press, 1981); James McWilliams, Building the Bay Colony: Local Economy and Culture in Early Massachusetts (Charlottesville, VA: University of Virginia Press, 2007). 
that connected both legislative bodies across the Atlantic. ${ }^{14}$ Furthermore, despite relocating themselves geographically and politically across the ocean, the emigrants, through familial, legal and cultural ties, 'maintained a strong sense of their identity as Englishmen'. ${ }^{15}$ Although not traditional exiles, the men and women of the MBC saw themselves as English expatriates whose religious beliefs had caused them to set out and establish their own autonomous governance. However, they were constantly aware that the autonomy they had obtained was a privilege granted to them by the English government through the company's charter and as such could be taken away at any point by that very government.

The MBC, once seen as a stopgap for a 'far more promising Caribbean location', is seen as a success story of English expansion and the planting of strong religious corporate governance in the Americas' north-east. ${ }^{16}$ This chapter explains how the flexibility granted to participants and members of the company through their corporate charter allowed them space to achieve autonomy and fuse their religious beliefs to the corporate governance of the company. Puritan or not, whether English, European or Native American, all who fell within their geographic jurisdictions were to be governed, and judged, under the authority of the MBC.

\section{The Plymouth Company and the Foundations of Theocratic Governance}

The north-east coastline of North America had for some years prior to the chartering of the MBC been the focus and scene of English religious Nonconformists experimenting and planting their ideas of religious governance. The MBC followed in the footsteps of the renowned Plymouth Colony, whose Puritan founders would share an intimate relationship with the MBC. ${ }^{17}$ To understand the political space of the commercial world

14 David Cressey, Coming Over: Migration and Communication Between England and New England in the Seventeenth Century (Cambridge: Cambridge University Press, 1987), p. 190; Tomlins, 'Legal Cartography', pp. 315-372.

15 Christopher D'Addario, Exile and Journey in Seventeenth-Century Literature (Cambridge: Cambridge University Press, 2007), p. 94.

16 Kupperman, Providence Island, 1630-1641: The Other Puritan Colony (Cambridge: Cambridge University Press, 1993), p. 1.

17 Rose-Troup, The Massachusetts Bay Company, especially chapters 1, 2 and 3. 
the MBC entered, as well as the godly New England its members wished to create, it is necessary to briefly discuss this Plymouth Company.

The Plymouth Colony was established in 1620, when the Nonconformists aboard the Mayflower landed in New England. That immortalised band of men and women who established Plymouth, glorified in the American imagination as the 'Pilgrim Fathers', have long been associated with fleeing religious persecution and governance in England during the sixteenth and seventeenth centuries. To understand the development of Puritan religious governance in New England, it is important to assess religious governance in England in the early years of James I's reign. At the same time, the evolution of religious governance and jointstock companies needs to be discussed when looking at the early years of the Plymouth Colony's existence. Furthermore, drawing attention to the period between 1620 and 1629 highlights the influence the Plymouth colonists exerted in foundation of the religious government of the MBC.

The accession of James VI and I to the throne of England was greeted by many reformers with the hope of further reformation in the Church, but they soon began to realise this was unlikely. James I quickly made it clear to Puritans, Presbyterians and other Nonconformists that he did not support their religious reform agenda, and that he actually hoped to bring them together. In doing so, James's actions set off a chain of events that laid the foundations for the ideas of religious governance that would be established in Plymouth and Massachusetts. In 1604 James I's comprehensive reassessment of Church law, canons and episcopal appointments, was perceived to be anti-reform by Puritans and Nonconformists, leading many Puritans to question the King's agenda and turn to migration from England as a means to escape the religious reforms of the monarch. ${ }^{18}$

The future governor of Plymouth and its first historian, William Bradford, had been an active member of the Gainsborough and Scrooby congregations, both of whom had come under religious scrutiny since 1602. ${ }^{19}$ Around the same time as prosecution of the Scrooby and Gainsborough churches, the future founder of Congregationalism and the

18 Winship, Godly Republicanism, p. 69; for complexities relating to achieving an alternative scholarly figure, see Foster, The Long Argument, pp. 99-101.

${ }^{19}$ For his history of the Plymouth Plantation, which ends with a 1651 list of the Mayflower Pilgrims and their descendants, see William Bradford, Bradford's History of the Plymouth Plantation 1606-1646, ed., William T. Davis (New York: Scribner's Sons, 1908) (hereafter Bradford, History). 
MBC religious model of governance, John Robinson, made contact with both congregations, calling them a 'hundred voluntary professors' ${ }^{20}$ By 1607, the two congregations at Gainsborough and Scrooby had come together in a joint enterprise. Bradford later fondly recalled the joining of the two churches, writing, 'they shook off this yoke of antichristian bondage, and as the Lord's free people, joined themselves (by a covenant of the Lord) into a church estate'. ${ }^{21}$ Between 1607 and 1608, the events surrounding the visitations and the congregations became public knowledge across the country. Although the minister Edward James called them 'his dear friends' he was dismayed to write that the members of the two congregations had 'severed yourselves from our assemblies', and appealed to them to re-join the national Church, comparing the fate of those outside the established Church to those who had not entered Noah's Ark. ${ }^{22}$ Meanwhile, the Lincolnshire native and Nonconformist Henoch Clapham applauded their actions writing from London that in farthest parts of Lincolnshire and Nottinghamshire' many had 'flatly already separated', establishing their own Church and religious governance. ${ }^{23}$ It was in this atmosphere of mounting pressure that the two congregations decided to emigrate to the safety of the Netherlands, escaping English religious and secular authorities, and taking their firsts steps towards New England.

After spending over a decade in the Netherlands, the congregation of covenanted Englishmen and women decided to remove themselves once again, setting to work at planting a truly godly government in America. Bradford gave four reasons for the group moving to America, each in some way related to the establishment, development and propagation of

${ }^{20}$ John Robinson, A Justification of Separation from the Church of England Against Mr. Richard Bernard, his invective entitled; The Separatist Schism (Amsterdam: 1610), p. 94.

21 Bradford, History, p. 31.

22 'None could be delivered from the deluge, but such as were contained in Noabs Ark: so can none be saved from eternal death, but only those who keep themselves within the Church of God', Edward James, A Retrayt sounded to certain brethren lately seduced by the schimaticall Brownists to forsake the Church (London: 1607), pp. 1, 5; for more on Edward James and a discussion surrounding a dialogue between Nonconformists and Anglicans in 1607, see Suellen Mutchow Towers, Control of Religious Printing in Early Stuart England (Woodbridge, Suffolk: Boydell \& Brewer, 2003), especially chapter 3.

23 Henoch Clapham, Errour on the Right Hand, through a Preposterous Zeal Acted by Way of a Dialogue (London: 1608), p. 14. 
godly governance and the gospel. ${ }^{24}$ However, to achieve this mission, its partakers needed to ensure some form of financial support from the godly in England. Their primary concern was to acquire a 'patent from one of the chartered trading companies' that had been established by the Crown to trade and govern over the new American territories. ${ }^{25}$ The Virginia Company of London had started offering patents to plantations that would pay tax to Jamestown to secure financial support for the faltering colony. In February 1619, after some negotiation, the VC granted the Pilgrims a patent to settle within its jurisdiction in the 'Northern parts of Virginia'. ${ }^{26}$ However, things were not to prove that simple; after the Mayflower returned to England in April 1621, it reported the news that the Pilgrims had landed and settled north of the VC lands, in the Jurisdiction of the Council of New England (CNE). Formerly the Virginia Company of Plymouth, the CNE in 1620 had been reformed and re-chartered under the new name, with the purpose of doing what the former company had failed to do, successfully establishing a permanent settlement and the 'Civil Society and Christian Religion' of English governance in New England. ${ }^{27}$ The Pilgrims sent back a request for the corporation to provide them with a patent to remain where they had settled, which was granted that same year. Known as the 'Second Pierce Patent', this was a temporary patent, and ensured that if a permanent settlement were not established, all the rights given would be reverted to the corporation. Despite the seven-year clause of the Pierce Patent, it provided the colonists with the constitutional apparatus they needed to establish themselves and their religious government legally in America.

Both this and future patents for the colony not only provided the legal validity for its existence, they provided the Plymouth colonists with the ability to establish their godly government. The Second Pierce Patent granted the Pilgrims the powers to govern over themselves and to make all 'laws Ordinances and Constitutions for the rule government' needed

$$
24 \text { Ibid, pp. 46-47. }
$$

25 Although primarily concerned with the cultural and family aspect of the colony, John Demos does offer a brief, if not fleeting, mention of the founding of a company in $A$ Little Commonwealth: Family Life in Plymouth Colony (Oxford: Oxford University Press, 2000), pp. 4-5.

26 The Patent no longer survives but is known as the 'First Pierce Patent'; Bradford, History, p. 107.

27 Charter of New England, (1620). 
to ensure the colonist could 'live together in the Fear and true Worship of Almighty God, Christian Peace, and civil Quietness', or in other words, godly government. ${ }^{28}$ The second patent contained remarkably little on how the colony should be governed, or on what direction the Council should develop its religious governance. On the subject of religion, the patent mentioned only that colonists were to 'build Churches, Schools, [and] Hospitals'.29 The religious governance of the colony had been defined a year earlier in the signing of the Mayflower Compact on 11 November 1620. The compact was designed by the initial migrants to supersede the original patent and to separate themselves further from English governance. Signed by 41 of the men aboard the Mayflower, the compact not only acknowledged that they had undertaken the project 'for ye glory of God, and advancement of ye Christian faith' but also set out how to establish this faith in their government. ${ }^{30}$ Through this formal act the signers sought to bring themselves 'together into a civil body politick' ${ }^{31}$ This civil body politic mirrored a Church covenant that bound the settlers' religious and political aims together to establish godly governance in America. In doing so they believed they could establish order in the colony and 'enact, constitute, and frame' godly 'equal laws, ordinances, Acts, constitutions, \& offices'. ${ }^{32}$ Although the second patent legally superseded the compact, its wording gave authority to the Mayflower Compact in all matters concerning governance of the colony. ${ }^{33}$ The Plymouth colonists combined the apparatus that provided the legal and constitutional foundations needed to establish governmental authority with their ideas and plans to establish their own godly government.

The structural organisation of the colony's government was also linked to its financial arrangements, as once they had secured their patent the

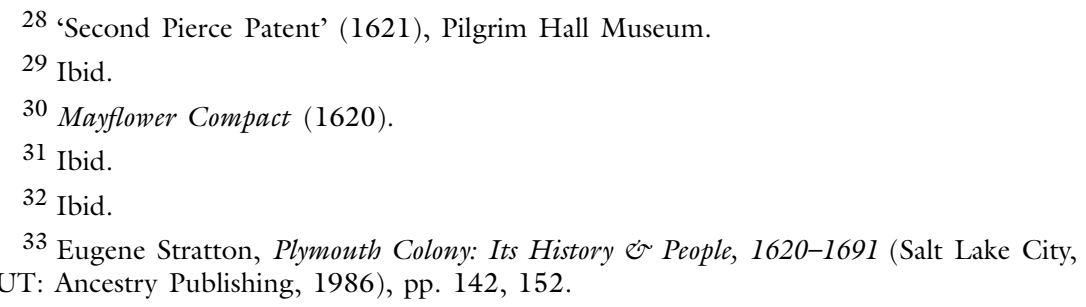


Pilgrims established a joint-stock company. ${ }^{34}$ Ruth McIntyre has convincingly argued that the Pilgrims organised themselves into something that was not dissimilar from the Virginia and Bermuda joint-stock companies. The colony's chief governing body was its court, which like many other seventeenth-century corporations was made up entirely of its stockholders. This was then broken into two bodies, the General Court made up of the freemen and a Court of Assistants that was an executive body made up of assistants along with the governor. Like the VC, EIC and later the $\mathrm{MBC}$, the $\mathrm{PC}$ shared a similar governmental structure based around the joint-stock corporate model. This combination of corporate governance with the planting of godly governance may not have been as explicit as it was with the MBC; however, like the VC, the Plymouth colonists established the experimental corporate foundations for the $\mathrm{MBC}$ government.

As to the financial structure of the Plymouth enterprise, 'the entire capital, including lands[,] was to be a joint stock fund, divided into shares'. ${ }^{35}$ All those over the age of sixteen who went to the colony were considered shareholders and every share was worth $£ 10 .{ }^{36}$ Investors could remain in England, and everyone who went to the colony and was a shareholder would continue in the joint stock for seven years. Over these seven years, all profits from several different industries, including trading and fishing, would remain in the common stock, in order to help furnish and supply the colony. After seven years, the profits and capital would be divided equally amongst the shareholders. However, the Pilgrims had incurred substantial debt to transport themselves to America, having borrowed from the Merchant Adventurers in London, who were repeatedly disappointed by the lack of profits from the colony. ${ }^{37}$ Attempts by the colonists in 1621 and 1625 to send back furs and pelts to their investors in London to pay off their debt were beset with bad luck. In 1621, the French boarded the ship and seized its cargo amounting to

\footnotetext{
${ }^{34}$ For a brief but in-depth analysis of the financial organisation of the Plymouth Colony, see McIntyre, Debts Hopeful and Desperate.

35 Ibid, p. 17.

36 William Scott, The Constitution and Finance of English, Scottish and Irish Joint Stock Companies to 1720, 3 vols. (Cambridge: Cambridge University Press, 1910), II: pp. 3078.

37 Bradford, History, pp. 272-273.
} 
$£ 500$, whilst in 1625 the ship was accosted by Barbary pirates in the Channel. ${ }^{38}$

Only a year before the pirates captured the ship, its captain, Emmanuel Altham, while trying to advertise the Plymouth Colony as an investment opportunity, argued that its colonists 'will flourish' if people were willing to invest. ${ }^{39}$ Altham drew attention to the religious morality and ethics of the colonists as a means of safeguard investment, linking the Plymouth brethren's religious governance to commerce. According to Altham, the 'New Plymouth will quickly return your money again. For on the most part they are honest and careful men' ${ }^{40}$ However, the Merchant Adventurers in London did not agree with Altham's suggestion that the Plymouth Colony was a sound investment and that success had been 'God grant[ed]', gradually withdrawing their financial and material support. Bradford recalled the reluctance of the Adventurers, who gradually sent fewer migrants and increased interest rates, leaving the colony in a difficult situation. Bradford complained that the colonists were left 'deeply engaged' in trying to secure the financial help to alleviate their economic situation. ${ }^{41}$ With some bitterness he wrote, 'the Company of Adventurers broke in pieces... and the greatest parte wholly deserted the colony' ${ }^{42}$ An agreement was reached in late 1626 between the then Assistant Governor Isaac Allerton and the Adventurers, in which the company bought its debt for $£ 1,800$ out of the $£ 7,000$, allowing those families resident in Plymouth advantageous land granting privileges. ${ }^{43}$

The following year, eight men in Plymouth, of which Mayflower migrants William Brewster, Bradford and Allerton are listed, and four

38 Nick Bunker, Making Haste From Babylon: The Mayflower Pilgrims and Their World: A New History, (London, Random House, 2010), pp. 307-308, 349; Bradford, History, p. 123.

39 Emmanuel Altham to James Shirley, May 1624, in Sydney V James ed., Three Visitors to Early Plymouth, ed., Sydney V. James, Jr. (Plymouth, MA: Plimoth Plantation, 2002), p. 49.

40 Ibid.

41 William Bradford, Governor Bradford's Letter Book, ed., John C. Kemp, (Plymouth, MA: Plimoth Plantation, 2002), p. 38.

42 Bradford, History, p. 201.

43 For a succinct discussion of the issues of the Plymouth Colony debt, see K. B. Patten, Isaac Allerton: First Assistant of the Plymouth Company (Minneapolis, 1908), p. 3; Bradford, History, pp. 271-274. 
in England sought to buy the rest of the debt from the Adventurers, and in turn, they were granted trading monopolies on fur by the other colonists. ${ }^{44}$ Those who remained in England and supported the Plymouth settlers were to be known as the 'Undertakers', who according to Bradford agreed to take upon themselves the debt of the whole colony. In the governors' opinion, this action had distanced the colony from the financial and governmental scrutiny of England, describing it as 'sett[ing] them free' and allowing its members to freely establish the religious government they wished. ${ }^{45}$ However, to ensure some financial return as well as secure their newly acquired trading monopolies, the 'Undertakers' also set about acquiring a new patent granting them access to areas known or suspected to be 'good trading places'. ${ }^{46}$ Yet even into the 1640 s, the town of Plymouth itself would continue to use the Plymouth Company covenant for land distribution, where the distribution of capital assets was based on shares in the company. ${ }^{47}$

The penultimate step to full governmental autonomy was taken in 1629 , the same year that the MBC received its charter, when the CNE finally granted the Plymouth colonists a third patent. The patent provided all the colonists and their 'heir and associates' permanent and more extensive rights to the lands in not only Plymouth but also Kennebec, Maine. ${ }^{48}$ Six years later in 1635, the CNE had its charter dissolved, yet despite this, the Plymouth Colony continued on in splendid isolation, as its patents along with its joint stock model of governance provided its colonists with the independence needed to successfully establish, maintain and develop their Nonconformist form of religious governance.

The constitutional and commercial apparatus that the Plymouth colonists had utilised along with their own brand of Puritanism provided a distinct Congregational form to the governance of the colony, which would later be adapted by the MBC. ${ }^{49}$ The religion of the Plymouth

44 For a list of the undertakers in both Plymouth and London, see the Articles for Agreement in Bradford, Letters, p. 40.

45 Ibid, p. 38; Bradford, History, pp. 226-228.

46 Bradford, Letters, p. 39.

47 William T. Davis, Records of the Town of Plymouth, vols. 3 (Plymouth, MA: Avery and Doten, 1889), I: pp. 4-6, 36-37, 62-70; Martin, Profits in the Wilderness, p. 137.

48 Warwick/Bradford Patent (1629), Pilgrims Hall Museum; Stratton, Plymouth, p. 141.

49 For more on the connection of the Plymouth and MBC and the New England way of religious governance see Maloy, Colonial American Origins, pp. 104-106. 
colonists permeated all aspects of their lives, including the government of the colony. Founding their civil government through the structure of the joint stock corporation, the Plymouth colonists quickly knitted the secular governance of the corporation to their faith. As early as 1622, both Bradford and Edward Winslow offered advice on how this could be implemented in the selection of government officials to be elected by the colonists. For both the elected and electors, those who were to govern were required to have fused together a desire for civil good with godliness of character. The people of Plymouth when electing their governing officials were reminded also not to be blinded by the cult of personality and not to be 'like unto the foolish multitude, who more honour the gay coat, than either the virtuous mind of the man' or most importantly 'the glorious ordinance of the Lord'. ${ }^{50}$ For the Plymouth colonists and those who would follow in the MBC, the success of their mission was often associated with the selection of godly leaders. Unlike in England, where the people were suppressed under the government of unelected and ungodly 'tyrannous Bishops', governance in Plymouth and Massachusetts would be firstly chosen by individuals who had the 'wisdom and godliness' to select those who recognised 'God's ordinance for your good'. ${ }^{51}$ By this means, the leadership of Plymouth sought to ensure not only the successful establishment of its religious governance but also that it could select who would lead the colonists in their mission.

During the first decade of the Plymouth Colony's existence, the leadership of the Congregational Church in the colony underwent a leadership crisis. ${ }^{52}$ This was magnified after the death of John Robinson, which one commentator described as leaving the colony's congregation as being left 'to feel the want of his help, and saw (by woeful experience) what a treasure they had lost'. ${ }^{53}$ Cracks in the unity of the colony began to form as ministers became scarcer and were unable to perform sacraments, particularly the two most important to Congregationalists: baptism and communion. In 1623, the situation was so dire that a senior member

\footnotetext{
50 Winslow and Bradford, Mourt's Relation or Journal of the Plantation of Plymouth (London: 1622), pp. xlv-xlvi.

${ }^{51}$ Bradford, A Late Observation as it Were, by the Way, Worthy to be Noted (1646); ibid, pp. xlv-xlvi.

52 Mark A. Peterson, 'The Plymouth Church and the Evolution of Puritan Religious Culture', New England Quarterly, Vol. 66. No. 4 (1993), pp. 570-593.

53 Bradford, History, p. 41.
} 
of the colony's elite, William Brewster, although unqualified, would lead his congregation in sermon and prayer. ${ }^{54}$ By 1630, the lack of ministers able to perform the sacraments was a cause of deep concern for leaders in Plymouth, as people such as Samuel Hicks and John Cooke questioned the existence of 'a visible Church and ordinances without a ministry' ${ }^{55}$ Both then demonstrated what the Plymouth leadership feared most, 'dissension in our Church', as the former became a Quaker and the latter was described as a 'Shallow man and Cause of trouble', an Anabaptist. ${ }^{56}$ The reaction of the Church was to cast them out of their society to ensure that their church congregation remained under the influence of the godly. Both the virtue and glorious ordinance they discussed could only be found amongst the godly members of their congregations. The government and those who governed the colony were then in an unbreakable covenant with the Pilgrims' Puritan Church, as members of both the Church and the government.

Excessively protective of their Puritan faith and Church, the Plymouth colonists became equally protective of their government by fusing Congregationalism to it. This protectiveness was not helped by a culture of religious and political paranoia. Scholars have studied what has been coined 'godly paranoia' in relation to the witch-hunts of the seventeenth century; however, very little has been said of the institutionalised paranoia of Puritan corporate religious governance in New England. ${ }^{57}$ Although paranoia is often associated with an individual, work by sociologists looking at millennialism in the modern age has produced a body of research based on game theory that suggests certain forms of paranoia

54 Although years later Bradford would claim that Brewster by experience 'was qualified above many' Bradford, History, p. 379; Plymouth Church Records 1620-1859 (Boston, MA: Colonial Society of Massachusetts, 1920), I: pp. 79-81.

55 Plymouth Church Records, pp. 92-93.

56 Peterson, 'Plymouth Church', p. 576.

57 Coffey and Lim, Companion to Puritanism, p. 9; for a brief discussion of paranoia, see Keith Thomas, Religion and the Decline of Magic: Studies in Popular Beliefs in Sixteenth and Seventeenth-Century England (London: Weidenfeld \& Nicolson, 1971), pp. 651652; for parallels between paranoia surrounding witch-hunts in seventeenth-century New England and the political paranoia of McCarthyism and the communist-hunts in 1950s America, see Robert S Robins \& Jerrold M. Post, Political Paranoia: The Psychopolitics of Hatred (New Haven, CT: Yale University Press, 1997), in particular chapter 8. 
can be termed social paranoia. ${ }^{58}$ Social paranoia is derived from social interaction where paranoid individuals, or a community, feel that they are being conspired against by others and as such 'are more aware of social realities, more alive to contingences and nuances, more strategic in their response'. ${ }^{59}$ This heightened awareness of the social realities of establishing a godly society in a hostile environment, along with the deep-rooted effects of religious and political life in England, left the Plymouth colonists deeply suspicious of the 'religious others', whether English, Native American or European. Gradually through the 1620s, as the Plymouth colonists established a government in New England that encapsulated both its corporate origins and its people's religious ethos, they also absorbed the religious and political paranoia that surrounded them. The effect of this was that the corporate religious government of the Plymouth colonists became increasingly hostile to those who did not share their doctrinal beliefs.

The cavalier Thomas Morton, the author of the New English Canaan, lawyer, colonist and scholar of Native American culture, faced the fury of Plymouth's leaders for his contrasting views and lifestyle. ${ }^{60}$ Described as 'an Elizabethan dandy, a man of the Renaissance, with a smattering of high culture and a hankering for low adventure', Morton stood as an antithesis to the Plymouth colonists. ${ }^{61}$ Bedford later remembered him as an 'instrument of mischief' and a 'man of more craft then honesty', whilst according to Bradford's colleague Edward Winslow, he was an 'arrant knave' and a 'serpent'. ${ }^{62}$ After a brief trip in 1622 to Plymouth, Morton settled in New England in 1624. He was part of a group of adventurers who established the settlement of Mount Wollaston, later named Merrymount. The establishment of the Merrymount trading post

58 John R. Hall, Philip D. Schuyler and Sylvanie Trinh, Apocalypse Observed: Religious Movements and Violence in North America, Europe and Japan (London: Routledge, 2000), pp. 189-216.

59 Stanford Lyman and Marvin B. Scott, A Sociology of the Absurd (Lanham, MD: Rowman \& Littlefield, 1989), p. 105.

${ }^{60}$ For more on the life of Thomas Morton, see William Heath, 'Thomas Morton: From Merry Old England to New England', Journal of American Studies, Vol. 41, No. 1 (2007), pp. 135-168; Thomas Morton, New English Canaan; or New Canaan (London: 1632) (hereafter New Canaan).

61 Heath, 'Thomas Morton', p. 136.

62 Bradford, History, pp. 250-251, 238; Winslow, in Winthrop Papers, 5 vols, (Boston, MA: Massachusetts Historical Society, 1944), IV: p. 428. 
upset the colonists in Plymouth; however, Morton very quickly 'raised their ire more'. ${ }^{63}$ This animosity towards Morton was rooted in religion and relations with the local Native Americans. Relations between the Plymouth colonists and Native Americans in the area, particularly the local Massachusetts, had been tense since the death of Squanto and Plymouth's attack on Wessagusset in $1623 .{ }^{64}$ In a move away from the traditional narrative of pilgrim apologists, Heath argues that their Native American policy was not as has been previously suggested 'humane and equitable' and that Wessagusset was not part of a plan by the Pilgrims to preserve 'interracial harmony', but it might be more accurate to suggest that they 'created a desert and called it peace'. ${ }^{65}$ It was in this environment of animosity between Plymouth colonists and Native Americans that Morton found himself increasingly on the side of the Native Americans. Writing some years later, he recalled how when he arrived in New England he "found two sorts of people, the one Christians, the other Infidels; these I found most full of humanity, and more friendly than the other'. ${ }^{66} \mathrm{He}$ would also recall how in his commercial dealings with the local Native Americans, establishing a moderately successful fur trade where the Plymouth colonists failed. Morton recalled how in his dealings with local Native Americans 'the more Savages the better quarter' he had leading to better trade and relations, however in opposition to this he scathingly wrote concerning the Plymouth colonists 'the more Christians the worse quarter I found'. ${ }^{67}$ It could be assumed that being English he would have found a great deal in common with the Plymouth colonists;

63 Mancall, The Trials of Thomas Morton: An Anglican Lawyer, His Puritan Foes, and the Battle for a New England (New Haven, CT: Yale University Press, 2019), p. 13.

${ }^{64}$ Squanto died in November 1622. For more on the Wampanoag Indian who helped the Plymouth colonists establish the colony, see Neil Salisbury, 'Squanto: Last of the Patuxets' in David G. Sweet and Gary B. Nash, eds., Struggle and Survival in Colonial America (Berkley, CA: University of California Press, 1981), pp. 228-246; Anna Brickhouse, The Unsettlement of America: Translation, Interpretation, and the story of Don Luis Velasco, 1560-1945 (Oxford: Oxford University Press, 2014), pp. 37-45; For the attack on Wessagusset, see Heath, 'Thomas Morton', pp. 143-148.

65 Heath, 'Thomas Morton', pp. 143-144; Alden T. Vaughan, New England Frontier: Puritans and Indians, -1775 (Boston, MA: Little, Brown and Company, 1965), pp. xiii, 88.

66 Morton, New Canaan, p. 15.

67 Ibid, p. 77. 
however, beyond the country of origin, there was not much in common between the two.

The strict Congregationalism of Plymouth was abstract to Morton, so much so that he saw more in common between England-or rather the hedonistic life-he had left and the Powhatan culture of festivity. Even the local Native Americans would 'exercise themselves in gaming, and playing of juggling tricks, and all manner of Revels, which they are delighted in'. ${ }^{68}$ Since Sir Humphrey Gilbert's voyages, traders had been aware that there was to be expected some form of entertainment accompanying commercial deals with Native Americans. ${ }^{69}$ Morton would have been fully aware that because of the obligation to provide entertainment upon the completion of a business transaction, he would fall under the heavy hand of the religious governance and envious Plymouth leadership. In May of 1627, in preparation for the completion of a business transaction, Morton ordered a maypole erected from an $80 \mathrm{ft}$ pine tree and made sure that they had 'brewed a barrel of excellent beer' for all those who came. ${ }^{70}$ Indeed, there was nothing out of the ordinary about such a festival, as they took place in his native England and in 1622 a precedent had been set when English fishermen in Maine had set up a maypole. ${ }^{71}$ Despite this, what was seen as 'harmless mirth' by Morton was perceived to be idolatrous and described as erecting a 'Calf of Horeb' by the 'precise Separatists' and as such worthy of godly punishment. ${ }^{72}$ Jealous of Morton and his men's trading success, Bradford scornfully wrote how he 'got much by trading with the Indians' and that they 'spent it as vainly, in quaffing and drinking both wine and strong waters in great excess'. ${ }^{73}$ Yet Morton evoked more than jealousy in the Plymouth leadership; his presence fuelled their social paranoia, as he seemed to have embodied not

68 Ibid, p. 20.

69 Edward Haies, 'A Report of the Voyages of Sir Humphrey Gilbert, Knight, 1583', in Henry Burrage, ed., Early English and French Voyages, 1534-1608 (New York: Charles Scriber's Sons, 1932), p. 192; Heath, 'Thomas Morton', p. 150.

70 Morton, New Canaan, p. 90.

${ }^{71}$ Phineas Pratt, 'A Declaration of the Affairs of the English People that First inhabited New England', Collection of the Massachusetts Historical Society, $4^{\text {th }}$ Series, Vol. 4 (Boston, MA: 1856), p. 478.

72 Morton, New Canaan, p. 90.

73 Bradford, History, p. 238. 
only all the reasons why they had left England but also what they worked so hard to establish a religious government against.

For the Plymouth leadership, Morton was irreligious, setting him immediately at odds with the deeply suspicious Congregational colonists, being accused of directing a 'school of Atheism'. ${ }^{74}$ This was likely a disparaging remark regarding Morton's Anglican faith that Plymouth leadership further imbued with irreligious connotations by suggesting it was centred around the 'idle or idol May-poll'. ${ }^{75}$ Bradford's conjunction drew together Puritan religious ideas surrounding idolatry and idleness. Morton's celebration according to Bradford was an expression of idleness, which was considered a cardinal sin. As one of Bradford's contemporaries pointed out, the 'industrious man hath no leisure to sin: the idle man hath not leisure to avoid sin'. ${ }^{76}$ In conjunction with idleness, Morton, by erecting the maypole, had also committed idolatry. Amongst Puritan circles, the maypole had long been considered a symbol of idolatry and was often the cause of conflict. In 1641, Puritan students in Oxford attacked a local maypole, whilst during the Interregnum, Parliament passed an order that all maypoles be taken down as they were considered 'a Heathenist vanity, generally abused to superstition and wickedness'. ${ }^{77}$ On top of these accusations, Morton was further charged with organised a bacchanalian orgy, to which were invited 'Indian women, for their consort, dancing and frisking together'. ${ }^{78}$ Although it is highly likely that Bradford exaggerated the accusations levelled at Morton, it is very clear that he was considered a threat. To Bradford and the other Plymouth

74 Ibid.

75 Ibid.

76 Ralph Venning, Milke and Honey, or a Miscellaneous Collation of Many Christian Experiences, Sayings, Sentences, and Several Places of Scripture Improved (London: 1653), p. 25.

77 Oxford Record Office PAR/207/4/Fl/l; C.H. Firth and R. S. Rait, Acts and Ordinances of the Interregnum, 1642-60, 3 vols. (London: His Majesty's Stationery Office, 1911), II: p. 1163.

${ }^{78}$ Mancall, Trials of Thomas Morton, p. 13. 
colonists, Morton, embodied England of Anglicanism, with its folk traditions that many Puritans had left behind, and so was an unwanted reminder of an old home. ${ }^{79}$

Morton's friendly trading relations with the Native Americans played upon the Plymouth colonists' fears of their indigenous neighbours, whom they perceived to be a 'cruel, barbarous \& most treacherous' people were not to be trusted. ${ }^{80}$ This was at a time when Wessagusset was still in the public's memory and the Plymouth Colony was still under the belief that colonists were being killed by Native Americans daily. Playing upon Plymouth colonists' fear, Morton was accused of trading and supplying the Indians with guns and shot. ${ }^{81}$ Not only this, but Bradford went further to suggest that if Morton and his men 'could attain to make saltpetre' they would have taught how to make gunpowder, 'O, the horribleness of this villainy! 82 Although the fear of armed Indians may not have been totally unwarranted, it was totally exaggerated, highlighting the Plymouth colonists' paranoia towards the Native Americans. ${ }^{83}$ Morton was arrested and tried by the Plymouth colonists in what has been described as a 'Kangaroo court' and sentenced to be 'sent back to England as a prisoner'. ${ }^{84}$ In a bizarre logic Plymouth's leadership brought two accusations against Morton that on one hand reinforced the colonies connection to the crown, while also illustrating the growing religiopolitical divide between the colony and England. The first was that he was accused of supplying arms to local Native Americans, which the Plymouth colonists argued was prohibited by a royal prohibition of King James. Secondly was also accused of trying 'to advance the dignity of Church of

${ }^{79}$ For an argument that Puritans neither disavowed nor encouraged arts and music, see Percy Scholes, The Puritans and Music in England and New England: A Contribution to the Cultural History of Two Nations (New York, Russell \& Russell, 1962).

80 Ibid, p. 47.

81 Ibid, pp. 239-240; Nathaniel Morton, New England's Memorial (Cambridge, MA: 1669), p. 92; Mancall, Trials of Thomas Morton p. 107.

82 Bradford, History, p. 240.

83 Nathaniel Morton, of no relation to Thomas Morton, illustrates this paranoia further by alluding to the fact that if the Indians did attack in the future, Morton would 'bear a greater part of the blame and guilt of it to future generations'; see Morton, Memorial, p. 92 .

${ }^{84}$ Heath, 'Thomas Morton', p. 156. 
England' within the jurisdiction of the colony. ${ }^{85}$ Morton and the events that surrounded his punishment were seen as a triumph for the religious governance and independence of New England and were embedded into the collective memory of the Congregational population. The heavyhanded approach of the Plymouth colonists and their leadership towards Morton not only illustrates the paranoia of the Congregational population but also how this paranoia became institutionalised in the religious governance of the colony.

\section{Chartering and Charter Rights}

The case of Morton was merely the foundation for what became an increasingly hostile, suspicious and closed form of corporate religious governance in New England. Between 1620 and 1629, the Plymouth colonists laid the foundations for the $\mathrm{MBC}$; their corporate religious governance along with their increasingly closed off society based on Congregationalist theology would become a building block for the newly formed trading company. Placing the MBC's charter in the religious and political context of the 1620s accentuates the nuances of the company's foundations, and with further scrutiny adds to the initial story of the MBC's charter, helping to illuminate the debates and reasons that led to transferal of the company's government abroad.

For corporations, their charters were the source of their power. As vestiges of a medieval civic tradition, charters were defined broadly, giving companies and corporations a wide variety of powers to protect, govern and legislate over the lands and people who lived in their territories. ${ }^{86}$ The level of the powers provided to companies by the charters were in themselves extraordinary when considered against the fact that over the seventeenth century those granting these powers were often considered arbitrary rulers. Furthermore, this is even more curious in the case of the MBC, especially when you consider that vocal communities of Puritans were granted these powers by Charles I, whom Puritan- and Presbyterian-inclined MPs within Parliament would accuse twenty years

85 Bradford, History, p. 241; Morton, New Canaan, p. 98.

86 Stern, Company-State, p. 10; Phil Withington, 'Citizens, Community and Political Culture in Restoration England', in Alexandra Shepard and Phil Withington, eds., Communities in Early Modern England (Manchester: Manchester University Press, 2000), p. 138. 
later of trying to 'introduce an arbitrary and tyrannical government'. ${ }^{87}$ Indeed, the traditional historiography has been based on the age-old tale of the Puritans fleeing religious persecution in England during a time when 'Parliament, liberty, property, and religion all appeared under attack from a sinister Catholic conspiracy against England with the King a co-conspirator, albeit perhaps unwittingly'. ${ }^{88}$ Jason Peacey has discussed Puritan ties that cemented links within the MBC during the 1630s being able to ensure that the company's fundraising efforts within England would be carried out in political and religious opposition to Charles I's personal rule. ${ }^{89}$ However, this traditional explanation for the founding of the MBC and its subsequent transferal across the Atlantic provides little justification for the chartering of the company by Charles, or for the convenient absence from the charter of clauses establishing where the company government should be held.

One hypothesis that attempts to answer these objections is that the events surrounding the chartering of the company and those leading to the transferal of its government abroad involved more cooperation between the Crown and the company's Puritan founders than previously presumed. The act of granting overseas company charters by Charles to Puritan groups whose supporters such as John Pym and Robert Rich, Earl of Warwick, opposed his religious and political policies suggests that Charles had his own agenda. ${ }^{90}$ Charles's creation of companies such as the MBC and Providence Island Company highlighted the double-edged nature of the Stuart monarchs' expansionist policy, which encompassed the King's religious, commercial and territorial aims in the Atlantic. Granted by the King, corporate charters legally formalised non-English spaces abroad according to English legal tradition, allowing Charles to dispose of pesky religious communities, whilst also advancing the financial and territorial aims of the King and country. Unlike the previous charters which established companies such as the VC, EIC and LC, the MBC's charter specifically left out any mention of where the company's government should be held. The 1606 Virginia charter stipulated that

87 An Act Erecting a High Court of Justice for the Trial of Charles I (1650).

88 Winship, 'Godly Republicanism', p. 439.

89 Peacey, 'Seasonable Treatises', pp. 667-679.

90 See BL, Add. Ms 11,692, Mss Letters 1634-1689, fo.1 John Pym to Alexander Pym November 21, 1634; John Wallis, Truth Tried: or Animadversions on a Treatise published by the Right Honourable Robert Lord Brooke, Entitled the Nature of Truth (London: 1642). 
'there shall be a Council, established here in England', whilst in 1620 the New England Company maintained a presence in England through its council in Plymouth. ${ }^{91}$ The omission of the clause stipulating that the company remain in England allowed the MBC to take full advantage of its charter and raise the possibility of moving the corporation and its charter out of the country. Considering that this omission allowed for a collection of people whom Charles would have considered to be a thorn in his side to move 3,000 miles away, it then does not seem too much of a leap to suggest that the ambiguity was deliberate on the part of the Crown and the company's Puritan officials. This effectively provided Charles with an outlet for future Puritan opposition groups in 1629. Although we now know this was not to be enough, at this point four years into Charles's reign the animosity between factions over religious persecution had not reached the levels it would in the 1630s and 1640s.

The complex relationship between Charles and the community and individuals of the MBC reached new heights of complexity in the leadup to the Wars of the Three Kingdoms. The Taunton Minister William Hooke, who had fled the religious policies of Charles in England and settled in Massachusetts, highlighted this complicated relationship. In 1640, he emotionally appealed to the members of the MBC to recognise the developing conflict in England whilst also emphasising the religious autonomy and separation from this conflict that the people of Massachusetts enjoyed. Although according to Hooke there was 'no Potentate breathing, that we call our dread Sovereign, but King CHARLES' and as such no 'Lawes of any Land have civilized us, but England's', he also believed the conflict in England to be an act of apocalyptic judgement against English religious governance or 'old England sins' and the monarch, which they had fled. ${ }^{92}$ Despite Hooke's affirmation of the monarch's position as 'dread Sovereign', he clearly believed that the MBC had obtained a level of autonomy that went beyond the geographical, and could be associated with its charter. This, however, did not mean that they stood in isolation. Hooke reminded his congregation not to forget the godly in Old England, who should never be 'forsaken

\footnotetext{
91 The Charter of New England, 1620.
}

92 William Hooke, New Englands Tears, for old Englands Fears. Preached in a sermon on July 23 1640, being a day of publike Humiliation, Appointed by the Churches in Behalf of Our Native Country in time of Feared Dangers (London: 1641), pp. 16-17, 23. 
in our affections'. ${ }^{93}$ Hooke's sermon alludes to the early foundations of the concept of dual sovereignty between the King and the charter that protected the colony and company under the laws of England, ideas that later came to define a series of political debates in the colony during the 1660s. Just as company officials were vigilant of the power of the monarch in the later years of the MBC's 57-year existence, so were its founders.

Further discussion of the possible cooperation between the company and the monarch can be expanded when the role of religious persecution within England under Charles and the established Church is questioned as a motivating reason in the choice to migrate to New England. The period of religious persecution under Charles's personal rule is often attributed to the rise of William Laud to the position of Archbishop of Canterbury in 1633 after the death of the Calvinist George Abbot. The period under Laud, often known as the 'Great Migration', saw substantial numbers of Puritans flee from religious persecution from Nonconformist strongholds in Yorkshire, the West Country and East Anglia as sympathetic bishops were replaced. ${ }^{94}$ Following the appointment of Laud, there was a swift change in pace in the religious governance of England. Archbishops and bishops sought to unify the ministry and theology of the Church into a body where there was little room for difference. From 1633 onwards, some religious communities across England felt that the Church under Laud and other bishops were pressuring, even persecuting, them into conformity. Faced with this threat, people in increasing numbers chose to migrate to New England. Across the decade, twenty ministers fled from London, seventeen from Norwich and eleven from the diocese of York and Chester. ${ }^{95}$ The scale of clerical migration was so high that even Richard Neil, Archbishop of York, complained to Charles in 1639 that 'too many of your Majesty's subjects inhabiting in these east parts of Yorkshire are gone into New England'. 96

Although the actions of Laud and his followers in the 1630s provide answers for the reasons for the role of English religious persecution in that decade, they do not account for the MBC's decision to transfer to New England in a period of comparative religious calm in England

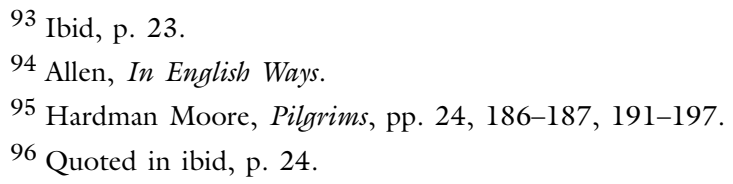


between 1629 and 1632. Indeed, in a pamphlet written upon the eve of his departure to Massachusetts, the governor of the MBC John Winthrop went so far as to suggest that the Congregational Church that he was leaving to join saw it as an 'honour, to call the Church of England, from whence wee rise, our dear Mother' ${ }^{97} \mathrm{He}$ went on further to suggest that the MBC could only succeed if those in the established Church 'consider us as your Brethren, standing in very great need of your help, and earnestly imploring it'. ${ }^{98}$ Similarly,Winthrop in his General Observations does not discuss the current state of English religious affairs but turns to Europe for his reason to leave, seeing the events in the Palatinate (1619) and La Rochelle (1627-1628) as signs 'to avoid the plague' that was sweeping over the continent. ${ }^{99}$ For Winthrop and his fellows, the jointstock company offered the best opportunity to avoid this plague, whilst also providing them with not only geographical space but the corporate and political arena to establish their theocratic government.

MBC directors were quick to call upon the need for theocratic governance in order for the company to be a success; they believed merging the company's trading aims with both evangelism and godly governance would provide them with the tools to succeed where others had failed. From the early stages of its existence, company officials were acutely aware of the failure of other English corporations, especially the VC claiming that the governors and government of the corporations involved in America had been 'unfit instruments'. ${ }^{100}$ The fundamental reason for their inadequacy was that 'their main end which was proposed was carnal and not religious' and that 'they aimed chiefly at profit and not the propagation of religion'. ${ }^{101}$ From this position, the MBC's investors and officials sought to avoid what they saw as the mistakes of previous companies by placing religion at the heart of the company's governance. They argued that the company would evangelise and propagate the gospel by

97 John Winthrop, 'The Humble Request of His Majesties Loyal Subject, the Governor and the Company late gone for New England; To the rest of their Brethren, in and of the Church of England. For the obtaining of their Prayers, and the removal of suspicions, and misconstructions of their intentions' (Boston, MA: 1630), p. 3.

98 Ibid, pp. 2-3.

99 Winthrop Papers, II: p. 113.

100 John Winthrop, 'General Observations for the Plantation of New England', in Winthrop Papers, II: p. 114.

101 Ibid. 
example, as its organisation mirrored the very specific Protestant values of those involved, not only effectively guaranteeing the company's religious success but also its financial prosperity.

Fusing together religion and trade in the first years of the company's existence, the MBC leadership considered them as founding pillars of their corporate structure, providing them with the freedom to achieve their specific aims and attain their goal of autonomous theocratic governance. Much akin to many contemporaries such as the Nonconformist cleric Henry Wilkinson, many MBC officials knitted together trade and religion, forming a standard seventeenth-century link. ${ }^{102}$ One official was to write that God had divinely knitted together the need for Protestants to spread 'the Gospel to all Nations' and the 'intercourse of Trade having opened up a passage, and made a way for commerce with the East and West Indies', thereby providing a spiritual and financial counter to Catholic expansion. ${ }^{103}$ Using religion, trade and evangelism to influence and gather the support of particular groups who had very different motives, the most important of these groups was the Crown. Thus, the company received the protection and freedom it needed to create a unique commonwealth in New England, eventually allowing the MBC to politically entrench a set of Puritan ideologies and practices in America that stood against everything the Anglican establishment considered 'English'. Yet, in the first year of the company's existence, a dialogue on its future governance looked very different to the Puritan zeal and financial redundancy that has come to define the MBC's theocratic rule of the colony; instead, it focused on religiously liberal and commercially viable options for the colony.

The rapid development of the MBC over the first decade of its existence from a trading company to a quasi-independent religious government has led to the mistaken presumption that trade was initially incompatible with the religious sentiments of the company's founders. However, the developments that saw the move from its role as primarily a trading company were never inevitable, and in fact, through the early years of its existence, the company continued the façade that it would trade. For those involved in the leadership of the $\mathrm{MBC}$, trade provided

102 Henry Wilkinson, The Debt Book: Or, a Treatise upon Romans 13 ver. 8. Wherein is Handled: The Civil Debt of Money or Goods, and Under it the Mixt Debt, as Occasion is Offered. Also, The Sacred Debt of Love (London: 1625).

103 'Sir John Eliot's Copy of the New England Tracts', in Winthrop Papers, p. 145. 
a reasoning to firstly obtain their charter and secondly to establish a foothold abroad and eventually lay the foundations of their religious government. Whether a possibility existed of financial returns or not, national prestige and a buffer on Catholic advancement in North America were incentives enough for Charles to offer a group of radical Puritans a corporate charter.

\section{MassaCHusetTS BAY COMPANY as Trading Corporation}

As is evident from the company's charter, the Crown expected to receive some financial return, mainly in the form of one-fifth of all gold and silver ore mining in the region. In addition, Charles and the MBC's leadership initially hoped that the company and the colony would obtain a foothold in the lucrative fur market, granting the company $50 \%$ of the beaver trade as well as encouraging growth in the North Atlantic fishing industry. ${ }^{104}$ In the years that followed it was the fur trade, governed by the MBC, that continued to attract a private group of investors such as John Oldham and Matthew Craddock. ${ }^{105}$ As Moore has pointed out, London 'supplied the colonies, with Boston merchants as smaller stakeholders in the enterprise'. ${ }^{106}$ Many of those who chose to migrate to the jurisdiction of the MBC did so 'with an eye for new opportunities in Atlantic trade', adding fur, timber and the North Atlantic fishing grounds to their mercantile connections in the Caribbean and the East. ${ }^{107}$ Even after the joint stock was dissolved, the business functions of the MBC did not cease. As late as the 1650s, the General Court still used land as a dividend to adventurers for those who had stock subscriptions, offering 200 acres for a $£ 50$ subscription. ${ }^{108}$ The granting of 'land as dividend to shareholders' highlights how MBC officials, almost a generation after 1629, continued to merge 'colony and company business' suggesting that the MBC was

104 RCM, I: pp. 4, 6, 11; The Charter of Massachusetts Bay (1629).

105 Bailyn, New England Merchants, pp. 27-28; Winthrop Papers, III: p. 379; IV: pp. 91-92.

106 Hardman Moore, Pilgrims, p. 105.

107 Ibid, pp. 4, 104-109.

108 Martin, Profits in the Wilderness, p. 136. 
than just a plantation corporation. ${ }^{109}$ Through the merging of colony and company's business, the MBC ably transitioned from a commercial joint stock venture to a politically religious corporation that assured its settlers it would ensure both the religious and commercial aims of its original inception.

Very quickly, the MBC transformed from a corporate organisation that governed over trade to a political structure that guaranteed the right to trade freely in the Atlantic world to those who fell under its theocratic governance. The MBC's leadership ensured this through several means including lobbying Westminster and actively expanding the colony's European and Caribbean markets. During and following the Wars of the Three Kingdoms, Parliament offered through the Navigation Act, along with other legislation, 'beneficial ordinance' and trading incentives to the MBC, such as trade without paying duties, which made MBC the envy of other colonies. ${ }^{110}$ During the conflict, the MBC's leadership tried to maintain its trading superiority by asking Parliament to ensure that Boston harbour remained a conflict-free zone. ${ }^{111}$ The MBC took advantage of conflict to increase its trade, becoming the 'very mart of the Land', exporting timber, farm produce, livestock and fish to numerous European countries and colonists in America, who according to Edward Johnson, member of the General Court, came to Boston 'for Traffic'. ${ }^{112}$ Johnson not only argued that Spain, Portugal, France and Holland 'hath all had a mouthful of bread and fish from us', but also that Massachusetts commodities had maintained England's Atlantic colonies, as well as the 'Grandmother of us all', England itself. ${ }^{113}$ John Winthrop some years earlier had noted that the success of Massachusetts trade and ship-building

109 Ibid, p. 136; Scott, Constitutions of Joint Stock Companies, II: pp. 312-315.

110 RCM, II: p. 34; Mercurius Britanicus, 60 (London: 2-9 December 1655), pp. 476477.

111 Massachusetts Records, III: pp. 31-32.

112 Edward Johnson, A History of New-England (London: 1654), p. 43; for the connection between the Wars of the Three Kingdoms and the development of ideas concerning free trade in the Atlantic, see Carla Gardina Pestana, The English Atlantic in an Age of Revolution, 1640-1661 (Cambridge; MA: Harvard University Press, 2004), chapter V; John J. McCusker, 'British Mercantilist Policies and the American Colonies' in Stanley L. Engerman and Robert E. Gallman, eds., The Cambridge Economic History of the United States Volume 1: The Colonial Era (Cambridge: Cambridge University Press, 1996), pp. 337-362.

113 Johnson, History of New-England, p. 208. 
was flourishing; a convoy of five ships had left the harbour for England, three of which had been built in Massachusetts. ${ }^{114}$ Unlike the EIC, from an early stage, the original commercial mission of the MBC did not remain the main focus of the company's members; this did not, however, mean that commerce did not play an important part in the decisions and religious aims of the MBC's theocratic governance.

For those initial investors, both religion and commercial gain were motivation enough to form and subscribe to the company. Robert Brenner has suggested this, pointing out that the MBC attracted substantial interest from London-based merchants 'with serious commercial as well as religious intentions'. ${ }^{115}$ These merchants had commercial interests across the globe. The MBC's first governor, Matthew Craddock, was an EIC merchant along with Samuel Vassell, whilst Nathan Wright had been involved in the Levant Company as well as arrested for interloping in the Greenland Company's trade. For these men, all of whom were Nonconformists, the MBC offered the possibility of a lucrative commercial venture and stock in a grander religious undertaking. Although neither Craddock nor Wright relocated with the company to Massachusetts, they maintained the company's interests in London and 'played a significant part in the colony's trade throughout the 1630s'. ${ }^{116}$ During the decade that followed the creation of the company, its officials insisted that the commercial role of the company should be managed, whether through the migration of specialist artisans and workers or through the raising of stock. ${ }^{117}$ Specialist migration was a cornerstone of the MBC commercial plan, as they were able to pull talent from specialist Puritan demographics due to the areas mostly being populated by Nonconformists suffering from almost twenty years of financial hardship. ${ }^{118}$ For those who were

114 James K. Hosmer, ed., Winthrop's Journal: History of New England, 1630-1649, 2 vols. (New York: Scribners, 1908), II: p. 490; for more on the flourishing Massachusetts trade and the development of the merchant community in New England, see William $\mathrm{H}$. Whitmore and Walter K. Watkins, A Volume Relating to the Early History of Boston Containing the Aspinwall Notarial Records from 1644 to 1651 (Boston: Municipal Printing Office, 1903), V: pp. 19, 24, 94, 101, 143, 152-154, 172, 229, 294, 301, 318, 356.

115 Robert Brenner, Merchants and Revolution, pp. 149-150.

116 Brenner, Merchants and Revolution, p. 151.

117 RCM, I: p. 147; II: pp. 56-57, 68.

118 Allen, In English Ways, pp. 163-169. 
involved in the company, whether in its leadership or through migration, the majority 'were puritans from a highly puritanized culture', thereby strengthening the religious aim of the company to establish a godly society. ${ }^{119}$ However, alongside the religious aims of the company were pressing financial concerns for its establishment, and these financial concerns, although not necessarily religious in origin, were ultimately used to ensure that the company could secure its goal of establishing theocratic governance.

The joint stock corporate model provided the company directors with the political and religious autonomy needed to establish its form of theocratic republicanism. Moreover, the corporate model mirrored the Congregational churches, and as such was an obvious choice for MBC officials. Historians of the MBC such as Michael Winship have tended to focus on the 'narrow band' taken up by the Congregationalist migrants from the broad religious spectrum of early modern England, providing an insight into the religious foundations of the colony government. ${ }^{120}$ Those who have wished to construct a progressive history of American republicanism have repeatedly turned to the 'democratic' make-up of the Congregational Church, and its covenants, which provided the primary model for republican governance in Massachusetts. For the Congregationalists that relocated to Massachusetts, the lines between civil and ecclesiastical governance were blurred, driving the Church to the centre of all civic life, breaking from the traditional Presbyterian ideology, which saw Church and state as separate spheres. ${ }^{121}$

\section{The Corporate Congregation AND Foundations of Theocratic Governance}

For the founders of the MBC, it is then not illogical to suggest that they chose the joint stock corporate structure as a secular base for their 'godly project' since it mirrored the same collectivism of their Church. A founding father of the Congregationalism and pastor to the 'Pilgrim

119 Ibid, p. 163.

120 Phil Withington, 'Public Discourse, Corporate Citizenship, and State Formation in Early Modern England', The American Historical Review, Vol. 112, No. 4 (2007), p. 1026.

121 Winship, 'Godly Republicanism', pp. 450-455. 
Fathers', John Robinson, before the Pilgrims left on the Mayflower, argued that the Church polity was 'the perfection of all polities' and as such provided the example for 'all other bodies political'. ${ }^{122}$ As such, the MBC adopted the structure of the Congregational Church, which emphasised a revaluation of traditional ideas of mixed government into a theocratic system. Explaining this, Robinson wrote that 'all these three forms have their places in the Church of Christ. In respect of him the head, it is a monarchy, in respect of the Eldership an Aristocracy, in respect of the body, a popular state'. ${ }^{123}$ For the members of the MBC, the implementation of this religious structure in which society would be ordered accordingly as God, the Church elders and Church members was the best way to ensure the establishment of a godly commonwealth. It is also worth noting that by 'popular state' Robinson did not mean a society that was democratic, but one entirely restricted to Church membership. The fellow Puritan cleric and associate of Robinson, Henry Jacob argued that societies organised like a Church which were 'formed, directed, and guided by the Pastor chiefly, and by the grave assistant Elders', were secure from the prospect of despotism as those leaders were elected and could be censured by Church members. ${ }^{124}$ This Church structure provided the base for the MBC's theocratic government, which was to be far from democratic. Dorchester preacher Richard Mather explained the transition from ecclesiastical governance to civic, writing in 1640 that it was a contradiction of liberty that 'free-men should take upon them authorities or power over free men without their free consent, and voluntary and mutual Covenant or Engagement'. ${ }^{125}$ Mather's argument draws attention to the idea that the civic governance of the MBC should be collective, wherein the popular state held the elective power over its officials; although this directly refers to the Church, joint stock corporations similarly shared in ideas of collectivism.

Both the Congregationalist Church and the joint-stock company shared similar underlying principles of democratic collectivism that were policed through the involvement of selective membership. As Purchas

122 Robinson, A Justification, p. 132.

123 Ibid, p. 133.

${ }^{124}$ Henry Jacob, The Devine Beginning and Institution of Christs true Visible or Ministeriall Church (Leyden: 1610), sig. A3v.

125 Richard Mather, An Apologie of Churches in New-England for Church-Covenant (London, 1643), p. 9. 
wrote about earlier attempts to settle New England, the joint stock corporation provided the structure for 'affecting the public good, or a regular proceeding in the businesses of Trade, to embrace an uniformity, and to join a community or joint stock together'. ${ }^{126}$ The unifying features of a joint stock corporation and the process of entering a collective were concepts that over the seventeenth century were becoming closely linked to religion, and were not only associated with Nonconformists. Even Charles I was to use joint stock as an analogy for the Church of England, describing how Nonconformists had tried to leave the 'joint stock of uniform religion', just as the MBC saw Quakers, Anabaptists and Anglicans as breaking away from the joint stock of their Church. ${ }^{127}$ Whether it was through stock holding or Church membership, electoral power was invested in the hands of a select group who under the uniformity of their shared interests could choose their leadership. The corporate joint stock structure provided the Congregationalist founders of the MBC with a foundation closely mirroring that of their Church, and as such equipped them with the secular and civic pillars upon which they could build their godly republic.

For those early settlers, the Congregationalist model of governance benefited both the Church and state, as it prevented the corruption of its government, since elections were kept within a godly franchise as those elected were members of the godly community. As Winship has pointed out, according to the MBC, the only 'source of civic virtue in rulers and ruled alike was godliness', and the only 'reliable sign of godliness was membership in a church that took policing itself seriously' ${ }^{128}$ For contemporaries such as John Cotton, government and governance were born out of the responsibility and right of a godly people to supervise their leaders from abusing their power, and in the eyes of God, only the saints were true people, so that a Christian government could only be considered righteous by its relationship with God's chosen saints. ${ }^{129}$ Although the concept of striving towards godliness was a common refrain

126 Samuel Purchas, Purchas his Pilgrimes (1625), X: p. 1831.

127 Charles I, Eikon Basilike (London: 1648), p. 237.

128 Winship, Godly Republicanism, p. 198.

129 John Cotton, An Exposition Upon the Thirteenth Chapter of the Revelation (London: 1656), pp. 108-112. 
amongst Christian groups in the seventeenth century, the Congregationalists of the MBC sought to use the concept to prevent any form of abuse by confining the control of the government to the godly. Building upon Congregationalist principles established by Robinson, the MBC believed that their leadership 'ought to submit themselves' entirely to God and the Church, the process of which would lead to a godly leadership obtaining greater authority both ecclesiastical and civic to 'advance his sceptre over themselves, \& their people by all good means'. ${ }^{130}$ The advancement of godly governance or 'Christ's sceptre' was then to be measured by the number of people that became enfranchised members of the Congregational Church and were able to have a say in the religious governance of the company. However, the existence of those within the company's jurisdiction who did not religiously conform encouraged the MBC from its inception to see godliness in evangelism and the spreading of its form of Protestant religious governance.

\section{Policing Religious Behaviour: The Antinomian Controversy and Early Attempts to Curtail MBC's Theocratic Governance}

For the leadership of the MBC, the aim of the company's theocratic governance was to regulate the communal behaviour of those who fell under the company's jurisdiction, by attempting to enforce denominational uniformity. However, despite the vigour with which the leaders of the MBC tried to establish a uniform society, they, like their corporate brethren in the EIC and LC, at times struggled to come to terms with the diversity of Protestant theology in its communities. Prior to 1640, reports of the MBC's heavy-handed theocratic governance had already been filtering back into England for some time. From 1636 onwards, information slowly began drifting across the Atlantic that 'Massachusetts was torn apart' by religious division surrounding the Antinomian controversy. ${ }^{131}$ Following the arrival of Anne Hutchinson and her husband, William Hutchinson, in Boston in 1634, both quickly became involved in the religious community of the town, her husband being elected to positions of authority in the church and local government, whilst Anne was

130 Robinson, Justification, p. 38.

131 Hardman Moore, Pilgrims, p. 6. 
respected for her ability to lead people to conversion. However, through her theological beliefs, Anne quickly became part of a controversy that shook the MBC to its core, eliciting a governmental response from leaders of the company that would solidify its theocratic governance and damage its reputation in England in the years before, during and after the Interregnum. ${ }^{132}$ Building upon the teachings of her spiritual mentor, John Cotton, Anne's preaching centred on ideas of 'free grace', which theologically placed her in opposition to MBC authorities. Open criticism of the MBC's 'sanctification' of godly behaviour over the inner seal of the Holy Spirit as a sign of true conversion deeply troubled the company's authority. Hutchinson's belief stemmed from Cotton's assertion that true faith was to be achieved by 'the spirit of God'. ${ }^{133}$ Under this belief, the individual's 'own salvation' and the 'salvation of the Church' or community could only be achieved by the 'Holy Ghost that dwelleth in us', as salvation could not be achieved through 'works in our justification' alone. ${ }^{134}$ Like Cotton's beliefs, however, Hutchinson placed less emphasis on judgement and consequently on the law of God. It was this that deeply troubled the leadership of the company, as it threatened the authority of its theocratic governance. ${ }^{135}$ Just as Broadgate threatened the weak religious cohesion of the corporate community in the LC, Hutchinson and her followers were a hazard to the religious uniformity and godly mission of the company, and so like Broadgate had to be cast out of the corporate community.

Antinomian meant 'against or opposed to the law', and thus Hutchinson's preaching questioned the legalistic ministry endorsed by the MBC leadership. It was their religious belief that salvation could only be achieved through a strict adherence to the Mosaic commandments. ${ }^{136}$ Furthermore, the government of the MBC was sensitive to possible

132 Emery Battis, Saints and Sectaries: Anne Hutchinson and the Antinomian Controversy in the Massachusetts Bay Colony (Chapel Hill, NC: University of North Carolina Press, 1962), p. 6.

133 Cotton, A Treatise of the Covenant of Grace, as it is Dispensed to the Elect Seed, Effectually unto Salvation. Being the Substance of Divers Sermons Preached upon Act. 7.8 (London: 1659), p. 175.

134 Ibid, p. 201.

135 David D. Hall, The Antinomian Controversy, 1636-1638: A Documentary History (Durham, NC: Duke University Press, 1990), p. 149.

136 Hall, The Antinomian Controversy, pp. 154-156. 
threats to its theocratic governance, which was heightened by rumours that Charles I was planning to revoke the company's charter. ${ }^{137}$ The arrival of Henry Vane in 1635 and his election as governor granted Hutchinson some political support. Vane was an open supporter of Anne's ministry and encouraged her to set up well-attended meetings. ${ }^{138}$ However, by the autumn of 1637, the MBC's leadership mounted an attack against Hutchinson and her supporters, after which the Antinomians lost key supporters in government. Furthermore, company leaders gained a valuable ally, namely Anne's mentor, John Cotton. Writing several years after the controversy, Cotton clarified his stance, proclaiming 'if any therefore shall accuse the doctrine of the covenant of free grace of Antinomianism say, it teacheth men freedom from the law of Moses.... we see how false any such aspersion would be'. ${ }^{139}$ Cotton's belief was shared by many of the MBC leaders, who saw any attempt to erode the pre-eminence of biblical law as dangerous to the fabric of their society and governance. Winthrop, once elected, immediately reacted to such concerns, sparking a conflict between himself and Vane on the direction of religious governance in the company. The former's victory would ensure and strengthen the MBC's theocratic governance and lead to the latter's migration back to England.

Upon his electoral victory, Winthrop imposed strict laws preventing the migration or admittance into MBC society of anyone who did not adhere to the theocratic governance of the company. These laws granted sweeping powers to magistrates to effectively constrict the religious makeup of MBC society. According to Winthrop, 'none should be received to inhabit with this Jurisdiction but such as should be allowed by some Magistrates', thereby preventing those deemed dangerous to the religious governance of the company from entering MBC society. ${ }^{140}$ Simply put, the 'intent of the law is to preserve the welfare of the body' and, in this situation, Winthrop believed the law was 'to have none received

137 Jenny Hale Pulsipher, Subjects unto the Same King: Indian, English, and the Contest for Authority in Colonial New England (Philadelphia, PA: University of Pennsylvania Press, 2005), p. 29.

138 Michael Winship, Making Heretics: Militant Protestantism and Free Grace in Massachusetts, 1636-1641 (Princeton, NJ: Princeton University Press, 2002), pp. 7, 30.

139 Cotton, The Covenant of Grace Discovering the Great Work of a Sinners Reconciliation to God (London: 1655), p. 134.

${ }^{140}$ Winthrop, Journal, I: p. 224. 
into any fellowship with it who are likely to disturb the same'. ${ }^{141}$ Vane, a keen supporter of religious freedom, had previously openly supported individuals who had called for more religious freedom and was directly opposed to the passing of this law. ${ }^{142}$ It was Vane's belief that this law would stifle the progress of the godly and the formation of godly government, arguing that, by this law, it will come to pass, that Christ and his members will find worse entertainment amongst us than the Israelites did amongst the Egyptians and Babylonians, than Abram and Isaack did amongst the Philistines'. ${ }^{143}$ Moreover, Vane argued that the actions of Winthrop and the MBC had taken too much liberty in the enforcement of their theocratic governance, encouraging on Christ's authority that 'there is no liberty to be taken, neither in church nor commonwealth[,] but that which Christ gives and is according to him'. ${ }^{144}$ Despite his objection to the law, Vane was unsuccessful in having it repealed, and consequently left the colony for England, where he advocated reform of religious governance that was to be inclusive of Protestant ideas. Following his exit from MBC politics, alongside the flight of the Antinomians such as John Wheelwright to New Hampshire, Anne Hutchinson was left with few allies. ${ }^{145}$ One month after Vane left Massachusetts, Anne was called before a court made up of notable members of the MBC's religious governance, including John Endecott, Hugh Peter, Thomas Weld, Israel Stoughton and John Eliot, most of whom disagreed with her theological beliefs. Hutchinson's trial predictably ended with her conviction and subsequent banishment-although it would take a Church trial in the following spring to successfully banish her from the colony. ${ }^{146} \mathrm{~A}$ threat to the effectiveness of the religious governance of the company,

${ }^{141}$ Winthrop, 'A Defense of an Order of Court, (1637)' in Thomas Hutchinson, A Collection of Original Papers Relative to the History of the Colony of Massachusetts-Bay (Boston, MA: Thomas and John Fleet, 1769), pp. 67-81, 69.

142 On the eve of the May election Vane read out a petition from the Antinomian John Wheelwright calling for freedom of religious practice, an action that Winthrop described at the time as 'out of Order' and against the rules of the court, Winthrop Journal, I: p. 219.

143 Henry Vane, 'A Brief Answer to a Certain Declaration, made of the Intent and Equity of the Order of Court,' in Hutchinson, Collection of Original Papers, p. 95.

144 Ibid, p. 87.

145 Winthrop, Journal, I: p. 294.

146 Battis, Saints and Sectaries, pp. 242-247. 
Anne Hutchinson was dealt with within the traditions of the MBC and the wider global corporate community; just as Broadgate did in the LC, Hutchinson and her supporters faced ostracism and banishment from the corporate community.

On both sides of the Atlantic, authorities saw the MBC's reaction to the Antinomian crisis as highlighting the success of the corporation's leadership in establishing and enforcing a form of English corporate theocratic governance. However, unlike its champions in Boston, authorities in London, in particular the Crown, viewed this success with suspicion and began to take steps to curtail the MBC's autonomy and revoke its charter. This reversal in the opinion of the Crown towards the autonomy of the company had been taking place since the middle of the 1630s. ${ }^{147}$ The MBC's autonomy was increasingly marked by its belligerence towards signs and symbols of English domestic authority on both sides of the Atlantic. As I have stated earlier, although the leaders and members of the MBC migrated across the Atlantic establishing their theocratic governance, this did not represent a total separation from the land they had left. ${ }^{148}$ Several factors, including familial, cultural, commercial, political and legal connections, ensured that those who settled in New England would remain tied to their homeland.

For the settlers, these connections represented a double-edged sword, both providing them with legal and political justification to create a government as well as representing a distant but present threat to that government and its autonomy. As early as 1630, hostile reports began to circulate in England relating to the MBC and its members. One Dorset resident wrote that everyone involved in the 'New England business' were 'rebels' and that 'those sort that are gone over are idolaters, captivates and separatists'. ${ }^{49}$ The MBC's leaders complained that many of the reports circulating in England were 'false and scandalous' and they were undermining their position and image across the Atlantic causing. As one commentator wrote, the rumours caused public perception in England to be 'ill-affected to our state at home', yet despite this, negative reports

147 D'Addario, Exile and Journey, pp. 38-41.

148 Ibid, p. 37.

149 Dorset Record Office, DC/DOB/8/1 Dorchester Borough Records and Court Book, November 1630 also quoted in Cressey, Coming Over, p. 22. 
of the company's government continued to be circulated in England. ${ }^{150}$ In 1632, Edward Howes wrote to his relative John Winthrop Jr that he had heard 'diverse complaints against the severity of your government' and to remind him of the threat in England, declaring that 'a thousand eyes' were 'watching over you to pick holes in your coats'. ${ }^{151}$ Howes's comments were particularly prescient, as they coincided with the initial attempts by Charles I to revoke the MBC's charter. ${ }^{152}$ Prior to the MBC receiving its charter, Charles I proclaimed his position to impose 'one uniform course of Government' in Virginia and New England whereby 'through our Whole Monarchy' the colony would 'depend upon Our Self, and not be committed to any Company or Corporation', which he argued were 'not fit nor safe to communicate the ordering of State affairs'. ${ }^{153}$ For many in the $\mathrm{MBC}$, this proclamation remained an ever-present threat, heightening their sensitivity to any attempt by the Crown to act upon this threat.

In particular, Howes, although a supporter of the MBC, was writing to Winthrop to encourage its leaders to 'endeavour in all mildness to do god[']s work', in the hope that the disapproving gaze of the English Crown would turn elsewhere. ${ }^{154}$ However, despite Howes's recommendation, the MBC continued to fiercely enforce its theocratic government. In 1631, news reached England of several whippings and banishments in response to criticism of the company's theocratic governance. These included the whipping of Thomas Foxe and Mr. Craddock for 'uttering malicious and scandalous speeches' and the cropping, whipping, fining and banishment of Philip Radcliffe for the same 'against the government and church of Salem', whilst Francis Perry was whipped for 'ill speeches \& misbehaviour toward his minister', and Henry Linne for 'writing to England falsely and maliciously against the government'. ${ }^{155}$

150 Young, Chronicles, p. 331.

151 'Edward Howes to John Winthrop Jr, 3 April, 1632', Winthrop Papers, II: p. 76.

152 Malcolm Gaskill, Between Two Worlds: How the English Became Americans (Oxford: Oxford University Press, 2014), p. 125.

153 'A Proclamation for the settling the Plantation of Virginia, May 13, 1625', in Clarence S. Brigham, ed., British Royal Proclamations Relating to America, 1603-1783 (Worcester, MA: American Antiquarian Society, 1911), p. 53.

154 'Howes to Winthrop Jr, 3 April, 1632', Winthrop Papers, II: p. 76.

155 John Noble, ed., Records of the Court of Assistants of the Colony of the Massachusetts Bay, -1692 (Boston, 1904), II, pp. 12, 16, 18-19; Winthrop Journal, I: p. 64, 67; Howe 
The outcome of the Antinomian controversy was a success for the conservative base of the MBC, who secured both the pre-eminence of religious orthodoxy and uniformity in the theocratic governance of the company. As news of the treatment of Hutchinson reached England, it would soon be followed by numerous reports of religious persecution from Massachusetts, as the MBC imposed its theocratic governance in the wake of its success against Anne Hutchinson and under the perception that they were inundated by 'abominable filthiness breaking in upon us' ${ }^{156}$ In London, the colonist Samuel Gorton exposed the overextension of the magistrate's religious powers, complaining that the company tried 'to maintain that outward form of worship' that they 'had erected to themselves' and tended to force their Church upon others. ${ }^{157} \mathrm{He}$ lamented that the $\mathrm{MBC}$ had abandoned those 'principles of Divinity wherein we had been instructed in our native Country, tending to faith towards God in Christ'. ${ }^{158}$ Writing to John Winthrop from England in 1646, George Downing, alluding to events surrounding Hutchinson and many others, warned the then governor that it was 'the law of banishing for conscience, which makes us stink everywhere'. ${ }^{159}$ In 1652, fresh claims surfaced of the religious persecution of two Baptists under the MBC's religious governance, following John Clarke's publication of Ill Newes from New-England, or, A Narrative of New-Englands Persecution. Clarke, a Baptist himself, had fled persecution to Rhode Island and, along with Roger Williams, was sent to London as an agent for the colony, describing the theocratic governance of the $\mathrm{MBC}$ as 'most unchristian,

in particular writes about hearing of the punishment of Philip Radcliffe describing the 'cutting of a Lunatic mans ears' see Winthrop Papers. III: p. 76.

156 Winthrop Papers, IV: p. 345.

157 Samuel Gorton, Simplicities defence against seven-headed policy. Or, innocency vindicated, being unjustly accused, and sorely censured by that seven-headed church-government united in New-England: or, that servant so imperious in his masters absence revived, and now thus re-acting in Nevv-England. Or, the combate of the united colonies, not onely against some of the natives and subjects but against the authority also of the kingdom of England, ... Wherein is declared an act of a great people and country of the Indians in those parts, ... in their voluntary submission and subjection unto the protection and government of Old England (London: 1646), p. 3; Gorton had returned to England under duress, and was described dismissively by Winthrop as a 'High and Palmy' individual, Winthrop Journal, II: p. 57.

158 Ibid.

159 MHSC, VI, $4^{\text {th }}$ series: p. 537. 
yea Antichristian'. ${ }^{160}$ It was no doubt in the wake of Clarke's publication that the MBC's migrants in London, Sir Richard Saltonstall, wrote to Cotton upon hearing 'what sad things are reported daily of your tyranny and persecutions in New-England, as you fine, whip and imprison men for the consciences'. ${ }^{161}$ The reaction by the MBC's governance may have been considered hypocritical on a religious level; however, from a corporate perspective, the leaders of the company did not act any differently from their counterparts in the East.

\section{CONCLUSION}

For those who left England in the years following the MBC's creation, the establishment and creation of a Protestant godly government were matched in importance only by the geographical and demographic advancement of the company's religious governance. As another factor in moving closer to godliness and subsequently godly religious governance, evangelism by individuals and the company was considered of vital importance. In a reply to Winthrop, his friend Robert Ryece (or Reyce) emphasised the importance of settling a Church that was capable of evangelising the company's religious government, writing after Winthrop had sailed with the fleet that 'there is no work deemed more lawful and more requisite, then the plantation and establishing of a true church for the propagating of true Religion and the Christian faith'. ${ }^{162}$ As the lines that distinguished the Church from the company's government began to fade, so the role of evangelism evolved into a political tool of acquisition, as willing or forced conversion effectively meant assimilation into the jurisdiction of the company. For the MBC, this did not just mean

160 John Clarke, Ill Newes from New-England or A Narrative of New-Englands Persecution. Wherein is Declared that while old England is becoming New-England is become Old. Also four Proposals to the Honoured Parliament and Council of State, touching the way to Propagate the Gospel of Christ (with small charge and great safety) both in Old England and New. Also four conclusion touching the faith and order of the Gospel out of his last Will and Testament confirmed and justified (London: 1652), in MHSC, II, $4^{\text {th }}$ series: p. 12; Pestana, The English Atlantic, pp. 145-146.

${ }^{161}$ Letter from Sir Richard Saltonstall to Mr. Cotton and Mr. Wilson, in Hutchinson, Collection of Original Papers, p. 401.

162 'Robert Ryece to John Winthrop, 1629', in Winthrop Papers, II: p. 127; for more information on Robert Ryece, see C. G. Harlow, 'Robert Ryece of Preston 1555-1638', Suffolk Institute for Archaeology, Vol. 32 (1970), pp. 44-75. 
the evangelism of natives, although the 'propagation of the gospel to the Indians' was to play a considerable role in the missionary aims of the company in the years after the Restoration. Rather, it was the spreading of religion to reinforce its model of Protestant religious governance. For many in the MBC, in the years between 1640 and 1660, this was the primary function of evangelism, especially in the wake of opportunities to spread the MBC's religious governance in England during the Wars of the Three Kingdoms and the Interregnum.

Over the first decade of its existence, the MBC successfully achieved almost full autonomy from the English state. First by obtaining its charter and then by removing themselves across the Atlantic, away from the full extent of the Crown's authority, the company established its own religious government, based on its Church. Its leadership successfully combined secular institutions such as the joint-stock company, commerce and the government with the theories and structure of the Congregationalist Church and evangelism to establish and expand its specific form of religious governance. For the MBC, everything temporal and spiritual that the company involved itself in embraced the idea of Congregational collectivism. Whereas the EIC, who were to embrace collectivism in a universal Protestant sense, empowered individual chaplains to enforce religious governance and thereby a moral code, the MBC established a theocracy, contorting democratic principles into a Congregational collective to establish communal religious governance. In the eyes of those who established the company, only through the enfranchised communion of the saints under a godly government would they be able to create a 'city upon the hill'. 
Open Access This chapter is licensed under the terms of the Creative Commons Attribution 4.0 International License (http://creativecommons.org/licenses/ by $/ 4.0 /$ ), which permits use, sharing, adaptation, distribution and reproduction in any medium or format, as long as you give appropriate credit to the original author(s) and the source, provide a link to the Creative Commons license and indicate if changes were made.

The images or other third party material in this chapter are included in the chapter's Creative Commons license, unless indicated otherwise in a credit line to the material. If material is not included in the chapter's Creative Commons license and your intended use is not permitted by statutory regulation or exceeds the permitted use, you will need to obtain permission directly from the copyright holder.

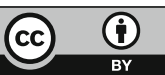

